\title{
Determinants of market outlet choices by smallholder teff farmers in Dera district, South Gondar Zone, Amhara National Regional State, Ethiopia: a multivariate probit approach
}

\author{
Tadie Mirie Abate* ${ }^{*}$, Taye Melese Mekie and Abebe Birara Dessie
}

${ }^{*}$ Correspondence:

tadym21@gmail.com

Department of Agricultural

Economics, College

of Agriculture

and Environmental Science,

University of Gondar, P.O. BOX

196, Gondar, Ethiopia

\begin{abstract}
In Ethiopia, teff is an important cereal crop, particularly in Dera district. It is a source of food and provides cash income for majority of smallholder farmers. To commercialize teff producers, selecting an appropriate market channel is mandatory. However, selecting an appropriate market channel is not an easy task because there are different factors that influence market outlet choices. Therefore, this study aimed to identify factors that influence teff market outlet choices. A two-stage random sampling procedure was used and a total of 154 smallholder farmers were randomly and proportionally selected to collect primary data. Multivariate probit model was employed to identify factors affecting teff market outlet choices. The result of the study shows that the probability of teff producers to choose wholesaler, retailer, consumer and cooperative market outlets was $31.82 \%, 35.71 \%, 37.01 \%$ and $16.88 \%$, respectively. This shows that consumer was the most likely chosen market outlet while cooperative was the less likely chosen market outlet. The joint probability of farmers to choose the four market outlets is (0.1\%) lower than the likely of no choosing four market outlets (19.5\%). The result of multivariate probit model revealed that age of household head, land size, quantity of teff produced, lagged price of teff, family size (AE), membership of cooperatives and distance to the nearest market were found to be statistically and significantly affecting the market outlet choice behavior of teff producers. This implies that improving the production capacity of farmers and invests on rural cooperatives would help smallholder farmers to choose the rewarding market outlet. Therefore, the study suggested that improving the existing production system, farmers relying on intensive cultivation; giving better price for farmers and being membership of cooperative are important strategies to select the appropriate market channel.
\end{abstract}

Keywords: Teff, Market outlet choice, Multivariate probit

\section{Introduction}

Commercializing smallholder agriculture is an indispensable path toward economic growth and development for most developing countries which rely on the agriculture sector including Ethiopia (Gashaw et al. 2015). According to MoFED (2015), the Ethiopian government, in its two-consecutive 5-year Growth and Transformation Plans (GTP-I and GTP-II), has given much emphasis for agricultural commercialization, 
among which the second pillar intends to achieve growth and thereby improve people's livelihoods and reduce poverty. The government of Ethiopia implemented agricultural commercialization clusters with the primary goal of commercialization of smallholders' agriculture and agro-industrial development, offering a strategic entry point for private sector engagement (Pauw 2017). According to Getahun Tefera (2018), commercialization of agricultural production is conceived as the process of agricultural modernization, specialization, and structural transformation of the economy toward more rapid and sustainable growth. Commercialization entails agricultural production decision, intended for market-based signals, offered produce for sale and use of purchased inputs.

In Ethiopia, cereal production and marketing are the main means of livelihood for millions of smallholder households. Among cereals, teff (Eragrostis teff) stands first in terms of land area coverage, followed by maize and wheat (SA 2016). Ethiopia is the center of both origin and diversity for teff (Vavilov 1951). Teff is a staple food and one of the most important crops for generating farm income, cultural heritage, national identity and nutritional security.

Teff is the most important cereal in terms of both production and consumption in Ethiopia, and is grown as food grain in only one other country, Eritrea. As the most preferred cereal crop, especially in urban areas, teff fetches a relatively high price in the market, making it an attractive cash crop for farmers. It is nutritionally rich with high levels of iron and calcium and has the highest amount of protein among cereals consumed in Ethiopia. Teff bread, locally known as injera, is a major staple food for many Ethiopians. In the country, teff is preferred over other grains. Even though, teff is more widely consumed by the economically better off urban residents than by rural households. Teff contributes up to $600 \mathrm{kcal} /$ day in urban areas as compared to only $200 \mathrm{kcal} /$ day in rural areas (Minten et al. 2013).

Studies have shown that income elasticity of teff is the highest among cereals, and greater than one in both urban and rural areas: a 1\% increase in income increases demand by more than $1 \%$. Teff is more of a luxury food for rural households and the urban poor, while maize and wheat are necessity food grains (Berhane et al. 2011). Teff is therefore an economically superior good that is relatively more consumed by the rich than by the poor. Teff is a commercial crop mainly because of the high price it fetches and the absence of alternative cash crops (such as coffee, tea or cotton) in the major teffproducing areas of Gojam (Amhara) and Shoa (Oromiya). Assemblers in village markets and wholesalers in regional markets pay close attention to the quality of teff (Minten et al. 2013).

In spite of the conducive agricultural commercialization policy environment, the return and incentive for growth in teff through agricultural commercialization face a number of demographic and marketing challenges (Pauw 2017; ATA 2017). There is a lack of information in terms of identifying factors affecting market outlet choices of teff producer particularly in Dera district, South Gondar Zone, Amhara National Regional State, which is one of the potential area of teff production in Northwestern Ethiopia.

Teff production in Dera district is mainly produced for market demand besides to consumption by smallholder farmers. In spite of teff is an economically, socially and culturally important crop, teff market channel choices' study has not yet been undertaken and assessed in the study area. To maximize the benefits that they may earn, farmers 
have to make appropriate decisions as to where they should sell their product. According to Office, DDA (2018), teff marketing is constrained by inadequate transportation network, limited numbers of traders and market outlets, inadequacy of credit access, weak bargaining power of producers, price instability, lack of storage facilities and weak market information. Market outlet choice is one of the most important farm household decisions to sell their produce in different marketing outlets and has a great impact on household income. Market outlet choices are household-specific decision and several drivers have to be considered as a basis for such decision. There is a need to understand the characteristics of the various teff marketing channels, and to enhance the capacity of farmers to make informed decisions regarding marketing channels. Understanding the factors that influence the choice of marketing outlet selection strategies is imperative since the exploitation of such strategies has the potential to increase crop production, investment and farm income (Soe et al. 2015). The information could further assist in developing strategies to mitigate the effect of some factors, thereby enhancing smallholder farmers' market access and increasing their chances of running a sustainable and profitable crop farming business. Muricho et al. (2015) argue that understanding the relationships between the marketing channels and the factors that determine the utilization of each market channel is fundamental in profiling the markets, as well as establishing policy interventions that are carefully designed to benefit farmers. Considering that each market channel is characterized by different profitability, risk, cost structure and other requirements (Soe et al. 2015), understanding these characteristics is beneficial to a smallholder producer who aims to access these market outlets.

Various empirical studies pointed out that smallholder farmer's decision to choose different market outlet can be affected by household characteristics, resource endowments, access to different market outlets' price and transportation cost. There are different market outlets selected by producers in order to sell their agricultural products to get maximum return. However, there are various factors that affect households' decision to select appropriate channel for delivering their products to the market. Identifying these factors is very important in terms of pinpointing possible areas of interventions that may help farmers to maximize benefits out of their teff production and marketing activities. Hence, this study aimed to identify factors that influence teff market outlet choices, in order to narrow the information gaps between producers, consumers, cooperatives, traders and other market participants. Therefore, understanding variables affecting market outlet choices of teff can be of great importance in the development of sound policies with respect to agricultural marketing, prices and overall rural and national development objectives of the country.

\section{Research methodology}

\subsection{Description of the study area}

The study was conducted in Ethiopia Amhara National Regional State South Gondar Zone specific to Dera district rural households. Amhara National Regional State is located at $9^{\circ}$ and $13^{\circ} 45^{\prime}$ North latitude and $36^{\circ}$ and $13^{\circ} 45^{\prime}$ East longitude. Dera is one of the districts in the Amhara Region of Ethiopia. Dera district is one of the 11 districts in South Gondar Administrative Zone. It is bordered on the south by the Abbay River which separates it from the West Gojjam Zone, on the west by Lake Tana, on the 


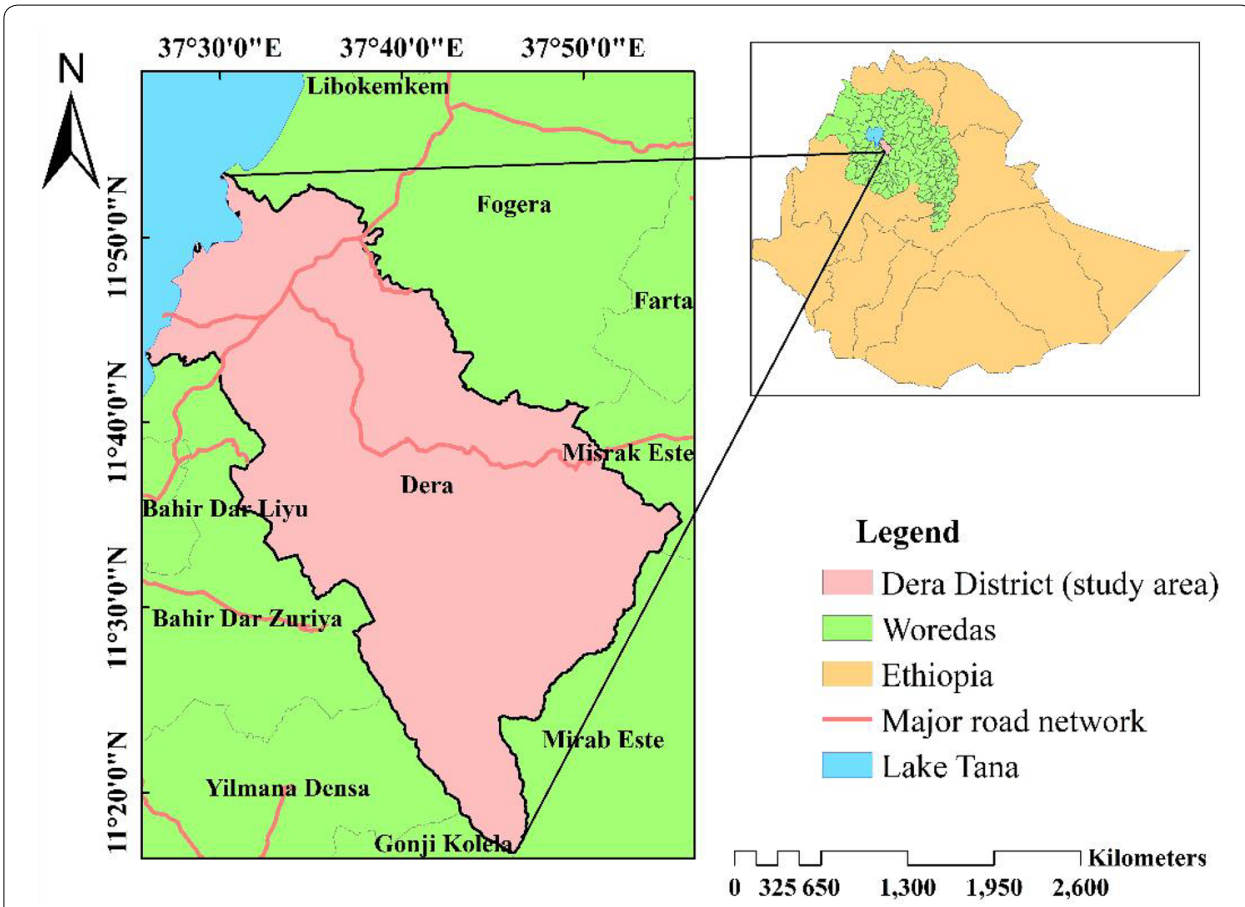

Fig. 1 Map of the study area

north by Fogera, on the northeast by East Este, and on the east by West Este (Mirie and Zemedu 2018).

Dera district is found $42 \mathrm{~km}$ from Bahir Dar, which is the capital city of Amhara Regional State and about $79 \mathrm{~km}$ from Debre Tabor, which is the capital city of South Gondar zone. The woreda lies between $37^{\circ} 25^{\prime} 45^{\prime \prime} \mathrm{E}-37^{\circ} 54^{\prime} 10^{\prime \prime} \mathrm{E}$ longitude and $11^{\circ}$ $23^{\prime} 15^{\prime \prime}-11^{\circ} 53^{\prime} 30^{\prime \prime} \mathrm{N}$ latitude with an area of 152,524.13 ha (Esa 2013). To total surface area of the district is $1525.24 \mathrm{~km}^{2}$ and known by potential teff production. The district is characterized under Woina Dega agro-ecological zone with an average rainfall ranging from 1000 to $1500 \mathrm{~mm}$ and its annual temperature is between 13 and $30^{\circ} \mathrm{C}$. The district altitude ranges between 1560 and 2600 m.a.s.l. Flat land accounts for $51 \%$ and mountain and hills the rest 49\% DDA (2018) (Fig. 1).

\subsection{Sampling technique and sample size}

A two-stage sampling procedure was employed to select potential teff producer households. First, five potential teff producer kebeles from the District were selected through purposive sampling method. During the selection, the kebele's potential for teff production and the accessibility of the areas to travel were taken into consideration. In the second stage, using the population list of teff producer farmers from sample kebeles, the intended sample size was determined proportionally to population size of teff producer farmers. Then, 154 representative households were randomly selected using simple random sampling technique using Yamane (1967) formula

$$
n=\frac{N}{1+N(e)^{2}}
$$


where $n$ is the sample size, $N$ the population size (total household size) and $e$ the level of precision. The population is homogeneous in terms of teff production in the sample kebeles. Due to the homogeneity of the population, $8 \%$ precision level was used for this study to avoid incurring additional costs and taking more time for collecting the same set of information on different small-scale teff producer farmers. Based on the number of the total households (9218) in the sampling frame, the formula equated and reached a minimum of 154 respondents to be drawn.

\subsection{Data source and data collection method}

Both primary and secondary data on a wide variety of variables were gathered to meet the objectives of the study. Primary data were collected through the administration of semi-structured and personal interview by a team of five trained enumerators to 154 small-scale teff farmers. Secondary data were collected from past reports and studies conducted by institutions and researchers.

\subsection{Data analysis}

Two types of analyses, namely descriptive and econometric analyses, were used for analyzing the collected data.

\subsection{Descriptive statistics}

The main descriptive statistics indicators that were employed are frequency, percentage, mean and standard deviations. This method of data analysis refers to the use of ratios, percentages, means, and standard deviations in the process of examining and describing marketing facilities, services and household characteristics.

\subsection{Econometrics analysis}

The appropriate econometric models that can help to identify the factors affecting market outlet choices of sample households are multivariate probit and multinomial logit model. Multivariate probit model was employed because of its advantages over multinomial logit model. Since multivariate probit model simultaneously set out the influence of a set of explanatory variables on choice of market outlets, while allowing for the potential correlations between unobserved disturbances as well as the relationship between the choices of different market outlets (Belderbos et al. 2004). In the study area, smallholder teff producers face different choices of market outlets like wholesalers, consumers, retailers and cooperatives. Thus, in this study teff is one of the cash crops that enable producers to choose more than one outlets that are not mutually exclusive to get better price. Considering the possibility of simultaneous choices of outlets and the potential correlations among these market outlet choice decisions, multivariate probit model (mvprobit) was appropriate and applied to capture household variation in the choice of market outlets and to estimate several correlated binary outcomes jointly.

The selection of appropriate market outlet $i$ by farmer $j$ is $Y_{i j}^{A}$ defined as the choice of farmer $j$ to transact market channel $i\left(Y_{i j}^{A}=1\right)$ or not $\left(Y_{i j}^{A}=0\right)$ is expressed as follows

$$
Y_{i j}^{A}=\left\{\begin{array}{c}
1 \quad \text { if } Y_{i j}^{A}=x_{i j}^{A} \alpha_{i j}+\varepsilon^{A} \geq 0 \Leftrightarrow X_{i j}^{A} \geq-\varepsilon^{A} \\
0 \quad \text { if } Y_{i j}^{A}=X_{i j}^{A} \alpha_{i j}+\varepsilon^{A}<0 \Leftrightarrow X_{i j}^{A}<-\varepsilon^{A},
\end{array}\right.
$$


where $\alpha_{i j}^{A}$ is a vector of estimators, $\varepsilon^{A}$ a vector of error terms under the assumption of normal distribution, $Y_{i j}^{A}$ dependent variable for market outlet choices simultaneously and $X_{i j}^{A}$ combined effect of the explanatory variables.

Univariate probit estimation of choice of each type of market outlet would be misleading for the expected problem of simultaneity. The selection of one type of market outlet would be dependent on the selection of the other, since smallholder farmers' choice decisions are interdependent, suggesting the need to estimate them simultaneously. To account for this problem, a multivariate probit simulation model was employed (Getahun Tefera 2018; Arinloye et al. 2015; Dessie et al. 2018; Melese et al. 2018). Since smallholder farmers' market outlet choice decisions were expected to be affected by the same set of explanatory variables

$$
\left\{\begin{aligned}
\text { Wholesaler }_{j} & =X_{1}^{\prime} \beta_{1}+\varepsilon^{A} \\
\text { Retailer }_{j} & =X_{2}^{\prime} \beta_{2}+\varepsilon^{B} \\
\text { Consumer }_{j} & =X_{3}^{\prime} \beta_{3}+\varepsilon^{C} \\
\text { Cooperative }_{j} & =X_{4}^{\prime} \beta_{4}+\varepsilon^{D}
\end{aligned}\right.
$$

where Wholesaler ${ }_{j}$, Retailer ${ }_{j}$, Consumer ${ }_{j}$ and Cooperative $_{j}$ are binary variables taking values 1 when farmer $j$ selects wholesalers, retailers, consumers and cooperatives, respectively, and 0 otherwise; $X_{1}$ to $X_{4}$ are vector of variables; $\beta_{1}$ to $\beta_{4}$ a vector of parameters to be estimated and $\varepsilon$ disturbance term.

In multivariate model, the use of several market outlets simultaneously is possible and the error terms jointly follow a multivariate normal distribution (MVN) with zero conditional mean and variance normalized to unity and $\rho_{i j}$ represents the correlation between endogenous variables, given by

$$
\begin{gathered}
\left(\begin{array}{c}
\varepsilon^{A} \\
\varepsilon^{B} \\
\varepsilon^{C} \\
\varepsilon^{d}
\end{array}\right) \cdots N\left[\left(\begin{array}{l}
0 \\
0 \\
0 \\
0
\end{array}\right)\left(\begin{array}{cccc}
1 & \rho_{12} & \rho_{13} & \rho_{14} \\
\rho_{21} & 1 & \rho_{23} & \rho_{24} \\
\rho_{31} & \rho_{32} & 1 & \rho_{34} \\
\rho_{41} & \rho_{42} & \rho_{43} & 1
\end{array}\right)\right] \\
E(\varepsilon / X)=0 \\
\operatorname{Var}(\varepsilon / X)=1 \\
\operatorname{Cov}(\varepsilon / X)=\rho .
\end{gathered}
$$

\section{Result and discussions}

\subsection{Demographic and socio-economic characteristics' sample households}

Table 1 presents the demographic and socio-economic characteristics of the sample households. The total sample size of the farm respondents handled during the survey was 154 . Out of the total sample respondents, $85.71 \%$ were male-headed households and the rest were female-headed households. Majorities of sample respondents were male-headed households in the study area (district). This implies that male-household heads have access of marketing information with good market networks due to the 
Table 1 Mean and proportion of sample households' characteristics. Source: Survey data result, 2018

\begin{tabular}{lcc}
\hline Continuous variables & Mean & Std. deviation \\
\hline Age (years) & 42.67 & 10.42 \\
Land size (hectare) & 1.73 & 0.93 \\
Quantity of teff (quintal) & 6.56 & 5.33 \\
Lagged price of teff per kg (ETB) & 10.58 & 1.29 \\
Total livestock unit (tlu) & 3.38 & 1.63 \\
Family size (number) & 5.72 & 2.05 \\
Distance to the market (walking hour) & 75.19 & 33.14 \\
\hline Dummy variables & Frequency & Percentage \\
\hline Sex of household head (male) & 132 & 85.71 \\
Education status of household head (literate) & 81 & 52.60 \\
Membership to cooperatives (yes) & 112 & 72.73 \\
Credit access (yes) & 106 & 68.83 \\
\hline
\end{tabular}

interaction ability with one or more teff product buyers than females who are in most cases restricted to home tasks.

As indicated in Table 1, the mean age of sample household heads was 42.67 years with standard deviation of 10.42 years, which implies that most of the sample households/ farmers were experienced in crop production. Similarly, the mean of teff yield produced by market sample households was 6.56 quintal/year with standard deviation of 5.33. If the amount of teff produced by sample households is high, farmers will select the appropriate market outlet for selling their yield. Likewise, the average land size owned by sample household heads was 1.73 hectare with a standard deviation of 0.93 . This implies that if a household heads owned large land size, they have a possibility to allocate relatively high land size for teff production which enters the increases in amount of teff produced and then farmers will have the probability of more appropriate market channel.

In terms of distance to the nearest market, the result indicated that the mean distance of household head from their home to the nearest market was 75.19 min with standard deviation 33.14. This implies that farmers who have nearer market have the possibility to sell their product to the appropriate market channel as compared to farmers who live far apart from the market. Most of the sample farmers have to walk a long distance from home to the nearest market to sell their agricultural products. Access to physical market infrastructure, like vehicle road, is fairly low in the villages thus farmers to take their commodities to the nearest market. Likewise, the average lagged price of teff was 10.58 ETB per quintal with standard deviation 1.29.

In terms of family size, the result indicated that the mean family size of sample households was 5.72 members per household with a standard deviation 2.05. Family size is a proxy variable for labor force which increases the production and productivity of teff. This implies that households who have a large number of family members have the possibility to sold their products for any appropriate market channel, because they cope up labor shortage for the transaction of teff product for different alternatives of market outlets. Similarly, the result of the study indicates that the average livestock owned by sample households was 3.38 numbers with standard deviation 1.63 . This implies that 
Table 2 Proportion of market outlets choosed by sample teff producers. Source: Survey data result, 2018

\begin{tabular}{|c|c|c|c|c|c|c|c|c|}
\hline \multirow{3}{*}{$\begin{array}{l}\text { Decision } \\
\text { to choose }\end{array}$} & \multicolumn{8}{|c|}{ Market outlets of teff producers } \\
\hline & \multicolumn{2}{|c|}{ Wholesaler } & \multicolumn{2}{|c|}{ Retailer } & \multicolumn{2}{|c|}{ Consumer } & \multicolumn{2}{|c|}{ Cooperative } \\
\hline & $N$ & $\%$ & $N$ & $\%$ & $N$ & $\%$ & $N$ & $\%$ \\
\hline Yes & 49 & 31.82 & 55 & 35.71 & 57 & 37.01 & 26 & 16.88 \\
\hline No & 105 & 68.18 & 99 & 64.29 & 97 & 62.99 & 128 & 83.12 \\
\hline
\end{tabular}

households that owned large livestock can generate high returns to cover high bargaining cost.

In terms of education status, the result of the study indicates that about $52.06 \%$ of sample households were literate while the remaining was illiterate. The educational background of the sample household heads is believed to be an important feature that determines the readiness of household head to accept new ideas and innovations. More educated farmers are expected to adopt new technologies to increase their land and labor productivities and also they have a tendency to select the appropriate market channel. Likewise, about $72.73 \%$ of sample households were memberships to rural cooperatives while the remaining was not a member of cooperatives. Moreover, about $68.83 \%$ of sample households have credit access while the remaining was not having credit access. Farmers with access to credit can minimize their financial constraints and they try to select the appropriate market outlets.

Teff producers in the study area sell their product in four market outlets. These were consumers which accounts for $37.01 \%$ of total sells followed by retailers, wholesalers and cooperatives with total sales of $35.71 \%, 31.82 \%$ and $16.88 \%$, respectively. This implies that farmers have limited market outlets to sell their produce. Therefore, the concerned body should give enough information for farmers to maximize the return of farmer from the sales of agricultural products (Table 2).

\section{Determinants of market outlet choices of teff producers}

The multivariate probit model was used to estimate several correlated binary outcomes jointly. In this study, the decisions of teff producers choosing wholesalers, retailers, consumers and cooperatives outlets are correlated. Since the decisions are binary, the multivariate probit model was found to be appropriate for jointly predicting these four outlet choices on an individual-specific basis and the parameter estimates are simulated maximum likelihood (SML) estimators. Thus, an econometric approach was employed to test the effects of the explanatory variables on the selection of a particular market outlet. The Wald $\mathrm{Chi}^{2}, \mathrm{X}^{2}(44)=109.47$, is statistically significant at $1 \%$ significance level (Table 3 ), which indicates that the subset of coefficients of the model is jointly significant and the explanatory power of the variables included in the model is acceptable.

The results of likelihood ratio test in the model show that likelihood ratio test of $\chi^{2}(6)=35.467$, Prob $>\chi^{2}=000$ is statistically significant at $1 \%$ significance level, indicating the null hypothesis that choices of the four market outlets is independent is rejected. That means the likelihood ratio test of the null hypothesis of independency between the market outlets' decisions $\left(\rho_{21}=\rho_{31}=\rho_{41}=\rho_{32}=\rho_{42}=\rho_{43}=0\right)$ is 
Table 3 Overall model fitness, probabilities, and correlation matrix of market outlet choices from the MVP model. Source: Survey data result, 2018

\begin{tabular}{|c|c|c|c|c|}
\hline Variables & Wholesaler & Retailer & Consumers & Cooperatives \\
\hline Predicted probability & 0.325 & 0.354 & 0.366 & 0.180 \\
\hline Joint probability of success & 0.001 & & & \\
\hline Joint probability of failure & 0.195 & & & \\
\hline \multicolumn{5}{|c|}{ Estimated correlation of market outlets } \\
\hline$\rho_{21}$ & & 0.039 & & \\
\hline$\rho_{31}$ & & 0.146 & & \\
\hline$\rho_{41}$ & & $-0.493^{* * *}$ & & \\
\hline$\rho_{32}$ & & $-0.379^{* * *}$ & & \\
\hline$\rho_{42}$ & & $-0.578^{* * *}$ & & \\
\hline$\rho_{43}$ & & $-0.298^{*}$ & & \\
\hline \multirow{2}{*}{\multicolumn{5}{|c|}{$\begin{array}{l}\text { Likelihood ratio test of } \rho_{21}=\rho_{31}=\rho_{41}=\rho_{32}=\rho_{42}=\rho_{43}=0 \\
x^{2}(6)=35.467 \text { and prob }>x^{2}=0.000^{* * *}\end{array}$}} \\
\hline & & & & \\
\hline \multicolumn{5}{|c|}{ Numbers of draws ((SML, \#draws) $=5$} \\
\hline \multicolumn{5}{|c|}{ Numbers of observation $=154$} \\
\hline \multicolumn{5}{|l|}{ Log likelihood $=-280.689$} \\
\hline Wald $x^{2}(44)=109.47$ & & Prob $>\mathrm{Chi}^{2}=0.000$ & & \\
\hline
\end{tabular}

significant at $1 \%$ level of precision, which shows the goodness of fit of Multivariate probit model. Therefore, the likelihood ratio test of independency indicated that there are different market outlet choice behaviors among smallholder teff producer farmers. In this study, samples are drawn 5 times to increase the accuracy, which indicates the precision level of the sample (Table 3 ).

The $\rho$ values $\left(\rho_{i j}\right)$ indicate that the correlation of each dependent variables (market outlet choices). The $\rho_{41}$ (the correlation between the choice of cooperative and wholesaler outlets), $\rho_{32}$ (the correlation between the choice of consumer and retailer outlets), $\rho_{42}$ (the correlation between the choice of cooperatives and retailer outlets) and $\rho_{43}$ (the correlation between the choice of cooperatives and consumer outlets) are negatively and statistically significant at $1 \%, 1 \%, 1 \%$ and $10 \%$ significance level, respectively. The result indicates that farmers selling their teff produce to the cooperative outlet are less likely to deliver to wholesaler, retailer and consumer outlets (Table 3 ).

The result in Table 3 also indicated the marginal success probability of each market outlet choices. The simulated maximum likelihood (SML) estimation result showed that the likelihood of choosing consumer outlet is relatively high (35.6\%) as compared to the probability choosing wholesaler outlet (32.5\%), retailer outlet (35.4\%) and cooperatives outlet (18\%). This result revealed that cooperative outlet is less likely chosen by teff producer farmers as compared to other outlets.

As indicated in Table 3, the joint probabilities of success or failure of choosing four outlets suggest that the likelihood of sample farmers to jointly choose the four outlets is low. The likelihood of sample teff producer farmers to jointly choose the four outlets was $0.1 \%$ which is lower compared to their failure to jointly choose them (19.5\%). This indicates that the possibility of choosing the joint market outlet is very low. This evidence suggests that choosing the right mix of market channels will be determined by different factors for each market channels. 
Table 4 Multivariate probit estimations for determinants of market outlet choices of teff producers. Source: Survey data result, 2018

\begin{tabular}{lcccc}
\hline Variables & \multicolumn{4}{l}{ Coefficients (choice of market outlet) } \\
\cline { 2 - 5 } & Wholesaler (1) & Retailer (2) & Consumer (3) & Cooperative (4) \\
\hline Age of household head & -0.024 & 0.014 & $-0.033^{*}$ & -0.004 \\
Sex of household head (male) & 0.540 & -0.630 & 0.060 & -0.044 \\
Education status & -0.106 & 0.345 & -0.141 & -0.167 \\
Land size allotted for teff & -0.077 & $-0.479^{* *}$ & $0.846^{* * *}$ & -0.057 \\
Quantity of teff produced & $0.0170^{* * *}$ & $0.101^{* *}$ & -0.040 & -0.001 \\
Lagged price of Teff & 0.200 & $0.236^{*}$ & -0.017 & 0.153 \\
Tropical livestock unit & -0.047 & -0.089 & -0.121 & 0.004 \\
Family size (AE) & -0.166 & 0.135 & $0.193^{*}$ & 0.040 \\
Membership to Cooperatives & $-0.720^{* *}$ & $-0.656^{*}$ & 0.120 & 0.187 \\
Credit access & -0.099 & -0.146 & -0.481 & 0.145 \\
Distance to the nearest market & 0.003 & -0.004 & $-0.008^{*}$ & $0.009^{*}$ \\
_constant & 0.055 & -2.350 & 0.496 & $-3.244^{*}$ \\
\hline
\end{tabular}

Dependent variable market outlet choices; ${ }^{* * *}, * *$ and ${ }^{*}$ are statistically significant at $1 \%, 5 \%$ and $10 \%$ significance level, respectively

The result in Table 4 indicated that out of 11 explanatory variables used in multivariate probit simulation model; age of household head, land size, quantity of teff produced, lagged price of teff, family size (AE), membership to cooperatives and distance to the nearest market were found to be statistically and significantly affecting the market outlet choice behavior of teff producers.

\subsection{Age of household head}

Age of household head was found to have a negatively and significantly effect in choosing consumer teff market outlet at $10 \%$ significance level. This implies that as the age of household increases by a year, the probability of farmers to sell their product to the consumer market outlet decreases by $3.3 \%$, ceteris paribus. This might be due to the fact that older peoples in Ethiopia are relatively illiterate as compared to younger peoples. Due to this, the older people do not know how much price can be received for selling a product from consumer market outlet that is relatively higher than selling a product to other market outlets. The reason for the price that can be received from selling a product to a consumer is higher than other market outlet is that producers can sell their produce to consumer market outlet without any interference.

\subsection{Land size under teff production}

The land sizes that can be allotted for teff production were found to have a negative and significant relation with the likelihood of choosing retailer market outlet while a positive and significant relation with the likelihood of choosing consumer market outlet at $5 \%$ and $1 \%$ significance level, ceteris paribus, respectively. The result of this study revealed that, as the land size allotted for teff production increases by 1 hectare, the probability of farmers to sell their produce to the retailer market outlet decreases by $47.9 \%$ and consumer market outlet increases by $84.6 \%$, ceteris paribus. This indicates that those households who allotted large size of land for teff production would produce more output and 
farmers would more likely to sell their produce to consumer market outlet and less likely to sell their produce to retailer market outlet. This means that farmers receive higher price from consumer market outlet as compared to retailer market outlet from the sale of teff product. This is because producers sold teff product to consumer market outlet without any interference. In other words, those with large parcels of land are likely to participate more in consumers' markets as they have scale advantage to reduce costs to take products to distance market. This result is consistent with Tefera (2014), who found that households with larger land size increase the probability of choosing consumer market outlet.

\subsection{Quantity of teff produced}

Quantity of teff produced by teff producers was found to have a positive and significance relationship with the likelihood of choosing wholesaler and retailer market outlet at $1 \%$ and $5 \%$ significance level, respectively. This result indicated that the quantity of teff produced by a farmer increases by a quintal, the likelihood of choosing wholesaler and retailer market outlet increases by $17 \%$ and $10.1 \%$, ceteris paribus, respectively. This implies that for a household who produce more teff products, farm households are more likely to choose wholesaler and retailer market outlets. This result is in line with Medeksa (2014) who found that the quantity of coffee sold to market agents increases, the probability of farm households choosing trader market outlets also increases. This result also consistent with Takele Honja and Mitiku (2017), who found that quantity of mango produced increases, probability of selling to the wholesalers is increasing. This is because wholesalers purchase high quantity of mango at once without selection.

\subsection{Lagged price of teff}

The lagged price of teff was found to have positively and significantly related with the likelihood of household heads choosing retailer market outlet at $10 \%$ significance level. This indicated that as the lagged market price of teff increases by a birr $/ \mathrm{kg}$, the probability household heads to choose retailer market outlet increases by $23.6 \%$, ceteris paribus. In contrary to this study, Takele Honja and Mitiku (2017) found that price of mango is negatively correlated with the probability of choosing retail market outlet. The reason for this study result is households/producers receive higher market price from the sale of teff as in retail market outlet as compared to wholesale market channel.

\subsection{Membership of cooperatives}

Membership in any cooperative by teff producers was found to have a negative and significant relationship with the likelihood of choosing wholesaler and retailer market outlet at $5 \%$ and $10 \%$ significance level, respectively. This result revealed that for those farmers who were members of cooperatives, the likelihood of choosing wholesaler and retailer market outlet decreased by $72 \%$ and $65.6 \%$, ceteris paribus, respectively, as compared to those farmers who were not members of any cooperatives. This implies that the households will sell fewer amounts of teff in the wholesale and retail market as compared to cooperative. This is mostly related to the reality that those multipurpose cooperatives passing down production and market information they accessed directly or indirectly to their members. This result is in line with Woldesenbet (2013), who found that 
households that were a members of any cooperatives negatively influence the probability of choosing collector market outlet. This result is also consistent with Tefera (2014), who found that households that were members of any cooperatives negatively influence the probability of choosing wholesale, retail and consumer market outlet.

\subsection{Distance from the nearest market}

Distance from the nearest market was found to have negative and significance relationship with the likelihood of choosing consumer outlet while positive and significance relationship with the likelihood of choosing cooperative market outlet at $10 \%$ significant level. This result revealed that those households whose residence from the nearest market increases by a kilometer, the likelihood of households choosing retailer market outlet decreases by $0.8 \%$ while the likelihood of households choosing cooperative market outlet increases by $0.9 \%$, ceteris paribus. This implies that households located far from the nearest market are less likely in delivering teff produce to retailer market outlet and more likely in delivering teff produce to cooperative market outlet. The reason for this is that farmers located distant from the market are weakly accessible to the retailer market outlet, and the closer to the market the lesser will be the transportation cost and time spent. This result is consistent with Getahun Tefera (2018), who found that distance to the market reduces the likelihood of producers to sell to wholesaler market outlet. This result is also in line with Alemu et al. (2012) who found that Ethiopian farmers located far from markets faced higher transaction costs, and so opted for cooperatives.

\subsection{Conclusion and recommendation}

The result of this study affirms that quantity of teff produced, membership to rural cooperatives, land size allotted for teff production, lagged price of teff, age of household head, family size and distance to the nearest market were found to be significantly influencing the choice of households' teff market outlet. The result of the study also shows that consumers are the most likely chosen market outlet while cooperatives are the less likely chosen market outlet. The joint probability of farmers to choose the four market outlets is lower than the likely of no choosing four market outlets. The probability of choosing wholesaler market outlet was affected by quantity of teff produced and membership to cooperatives. The probability of choosing retailer market outlet was affected by land size allotted for teff, quantity of teff produced, lagged price of teff and membership to cooperatives. The likelihood of households to choose consumer market outlet was affected by age of household head, land size allotted for teff, family size and distance to the nearest market. Likewise, the probability of households to choose cooperatives market outlet was affected by distance to the nearest market. Hence, based on the finding of this study, the concerned bodies should give information for farmers on the importance of being a member of cooperatives because farmers get inputs at a lower price and at convenience time for teff production and get better price in marketing activities of their teff products and facilitate the time to search the appropriate market channel. Appropriate policies should be strengthening to facilitate all necessary infrastructures for improving teff production and marketing system. This means that the concerned body should establish teff market center near to farmer's residence or production area. Farmers should rely on intensive cultivation to increase the production and productivity of teff. The study also 
suggested that improving the existing production system, farmers relying on intensive cultivation; giving better price for farmers and being membership for any cooperative are important strategies to select the appropriate market outlet. Generally, strong intervention could be taken by government to upgrade producers through improving trade regulation of teff.

\section{Abbreviations}

AE: adult equivalent; ATA: Agricultural Transformation Agency; CSA: Central Statics Agency; D.D.A: Dera district Agriculture; ETB: Ethiopian Birr; GTP-I: Growth and Transformation Plan-I; GTP-II: Growth and Transformation Plan-II; MoFED: Minister of Finance and Economic Development; MVN: multivariate normal distribution; Mvprobit: multivariate probit; SML: simulated maximum likelihood.

\section{Acknowledgements}

The author would like to thank the University of Gondar since financial support for this research was obtained from University of Gondar. Moreover, we thank the data respondents, enumerators and district experts for their valuable response during data collection process

\section{Authors' contributions}

All authors read and approved the final manuscript.

Funding

The University of Gondar provided financial support to complete this research successfully.

\section{Availability of data and materials}

The author wants to declare that they can submit the data at any time based on publisher's request. The datasets used and/or analyzed during the current study will be available from the author on reasonable request.

\section{Ethics approval and consent to participate}

Ethical clearance letters were collected from University of Gondar research and community service directorate and Dera district of face to care for both the study participants and the researchers. During survey, of facial letter was written for the study, District informed verbal consent was obtained from each client, and confidentiality was maintained by giving codes for each respondent rather than recording their name. Study participants were informed that clients have a full right to discontinue or refuse to participate in the study. Hence, all participants throughout the research, including survey households, enumerators, the supervisors and key informants were fully informed of the objectives of the study. They were approached friendly in free moods until then do this research.

\section{Consent for publication}

Not applicable.

\section{Competing interests}

The authors declare that they have no competing interests.

Received: 20 February 2019 Revised: 15 October 2019 Accepted: 19 October 2019

Published online: 07 November 2019

\section{References}

Alemu AE et al (2012) Vertical coordination in the local food chains: evidence from farmers' in Ethiopia. Int J Econ Fin Stud $4(1): 11-20$

Arinloye D-DA et al (2015) Marketing channel selection by smallholder farmers. J Food Prod Market 21(4):337-357

ATA 2017 Agricultural Transformation Agenda. Annual Report of 2016-17. Addis Ababa, Ethiopia

Belderbos R et al (2004) Heterogeneity in R\&D cooperation strategies. Int J Ind Organ 22(8-9):1237-1263

Berhane G, Paulos Z, Tafere K, Tamru S (2011) Food grain consumption and calorie intake patterns in Ethiopia. IFPRI Ethiopia Strategy Support Program II (ESSP II) working paper 23, pp 1-18

CSA, agricultural sample survey 2015/2016 (2008 E.C): report on area and production of major crops, volume-I. Addis Ababa, Ethiopia., 2016

Dessie AB, Abate TM, Mekie TM (2018) Factors affecting market outlet choice of wheat producers in North Gondar Zone, Ethiopia. Agri Food Secur 7(1):91

Esa E (2013) Land suitability assessment for sorghum and maize crops using a SLA and GIS approach in Dera Wereda, ANRS, Ethiopia. Ethiopian Renaissance J Soc Sci Humanit 1(1):119-139

Gashaw BA, Habteyesus DG, Nedjo ZS (2015) Analysis of marketed surplus of coffee by smallholder farmers in Jimma zone, Ethiopia. J Biol Agri Healthcare 5(5):242-252

Getahun Tefera A (2018) Determinants of commercialization and market outlet choices of Tef: the case of smallholder farmers in Dendi District of Oromia, Central Ethiopia, Haramaya University

Medeksa MJ (2014) Smallholders' Market outlet choice under different performance level of primary coffee marketing cooperatives: the case of Jimma Zone, Southwestern Ethiopia. J Econ Sustain Dev 5(27):93-100

Melese T, Goshu D, Tilahun A (2018) Determinants of outlet choices by smallholder onion farmers in Fogera district Amhara Region, Northwestern Ethiopia. J Horticult For 10(3):27-35 
Minten B et al (2013) Ethiopia's value chains on the move: the case of teff. Ethiopia Strategy Support Program II Working Paper 52:1-26

Mirie T, Zemedu L (2018) Determinants of market participation and intensity of marketed surplus among teff producers in Dera district of South Gondar Zone, Ethiopia. J Dev Agri Econ 10(10):359-366

MoFED (2015) Growth and transformational plan (GTP 2015-2020). Addis Ababa. Ethiopia

Muricho G, Kassie M, Obare G (2015) Determinants of market participation regimes among smallholder maize producers in Kenya

Office, DDA (2018) Draft report on agriculture production and productivity and agro ecology of Dera district, Ethiopia Pauw S (2017) Agricultural commercialization in Ethiopia: a review of warehouse receipts in the maize, wheat, sorghum and teff value chains. USAID/Ethiopia Agriculture Knowledge, Learning, Documentation and Policy Project, Addis Ababa.,

Soe WPP, Moritaka M, Fukuda S (2015) An analysis of the factors influencing marketing channel choice by paddy rice farmers in Myanmar. J Fac Agri Kyushu Univ 60(2):535-542

Takele Honja EG, Mitiku A (2017) Determinants of market outlet choice of the smallholder mango producers: the case of Boloso Bombe Woreda, Wolaita Zone, Southern Ethiopia: a multivariate probit approach. Glob I Sci Front Res: D Agric Vet 17(2):22-30

Tefera T (2014) Analysis of chickpea value chain and determinants of market options choice in selected districts of southern Ethiopia. J Agric Sci 6(10):26

Vavilov NI (1951) The origin, variation, immunity and breeding of cultivated plants. Soil Sci 72(6):482

Woldesenbet AT (2013) Value chain analysis of vegetables: the case of Habro and KombolchaWoredas in Oromia Region, Ethiopia. School of Agricultural Economics and Agribusiness, School of Graduate Studies, Haramaya University Yamane T (1967) Elementary sampling theory. Prentice-Hall, Inc., Englewood Cliffs, pp 371-390

\section{Publisher's Note}

Springer Nature remains neutral with regard to jurisdictional claims in published maps and institutional affiliations.

\section{Submit your manuscript to a SpringerOpen ${ }^{\circ}$ journal and benefit from:}

- Convenient online submission

- Rigorous peer review

- Open access: articles freely available online

- High visibility within the field

Retaining the copyright to your article

Submit your next manuscript at $\gg$ springeropen.com 